\title{
THE MESOZOIC CARBONATE DEPOSITS FROM THE BOREHOLE 6042 DELENI (TRANSYLVANIAN DEPRESSION)
}

\author{
IOAN I. BUCUR ${ }^{1}$, MARCEL-ADRIAN PITEIU ${ }^{2}$ \& EMANOIL SĂSĂRAN ${ }^{1}$
}

\begin{abstract}
The borehole 6042 Deleni is among the few wells located in the central part of the Transylvanian Depression that crossed the rocks in the basement. Among these, the Mesozoic deposits were cross-cut along $916 \mathrm{~m}$. Based on the investigations carried out on core samples from the Mesozoic deposits three carbonate units attributed to the Late Oxfordian -Tithonian (?Neocomian) have been separated. A preliminary evaluation of the terrigenous and carbonate-terrigenous deposits overlaying the carbonate ones indicated an Aptian-Albian, respectively Senonian age. Considerations on the paleoenvironment of the Mesozoic deposits studied are also presented.
\end{abstract}

Keywords: Carbonate rocks, biostratigraphy, Mesozoic, Transylvanian Depression

\section{INTRODUCTION}

The borehole 6042 Deleni crossed carbonate deposits on a total thickness of $916 \mathrm{~m}$ (between m. 3664 and m. 4580). Seventy six meters were sampled (Figs.1A-B, 2A-D) and 147 samples were investigated. Based on lithological features, three carbonate rock units have been separated as follows (from the base to the top, Fig.2):

1. Dolomitic limestones with Cladocoropsis (2 m thick, between m. 4580-4578);

2. Dolomites (427 m total thickness, between m. 4578-4151, of which $66 \mathrm{~m}$ were effectively sampled);

3. Limestones with cyanobacteria and Clypeina (487 m, between m. 41513664 , of which $9.5 \mathrm{~m}$ were effectively sampled).

The limestones and dolomites are overlaid by terrigenous and carbonateterrigenous rocks (sandstones, siliceous shales, clayey-silty limestones) (253 m thick, between m. 3595-3342, of which $9 \mathrm{~m}$ were effectively sampled). Fourteen samples were investigated in this interval.

Data concerning the general structural features of the Transylvanian Depression were published by Săndulescu \& Visarion (1978) and Săndulescu (1984).

\footnotetext{
${ }^{1}$ Babeş-Bolyai University, Department of Geology, str. M. Kogălniceanu nr.1, 400084 Cluj-Napoca, Romania. E-mails: ibucur@bioge.ubbcluj.ro; esasaran@bioge.ubbcluj.ro

2 SNGN "Romgaz" S. A. Mediaş, Str. Unirii No 4, 3125-Mediaş. E-mail: marcel.piteiu@medias.romgaz.ro
} 
IOAN I. BUCUR, MARCEL-ADRIAN PITEIU, EMANOIL SĂSĂRAN

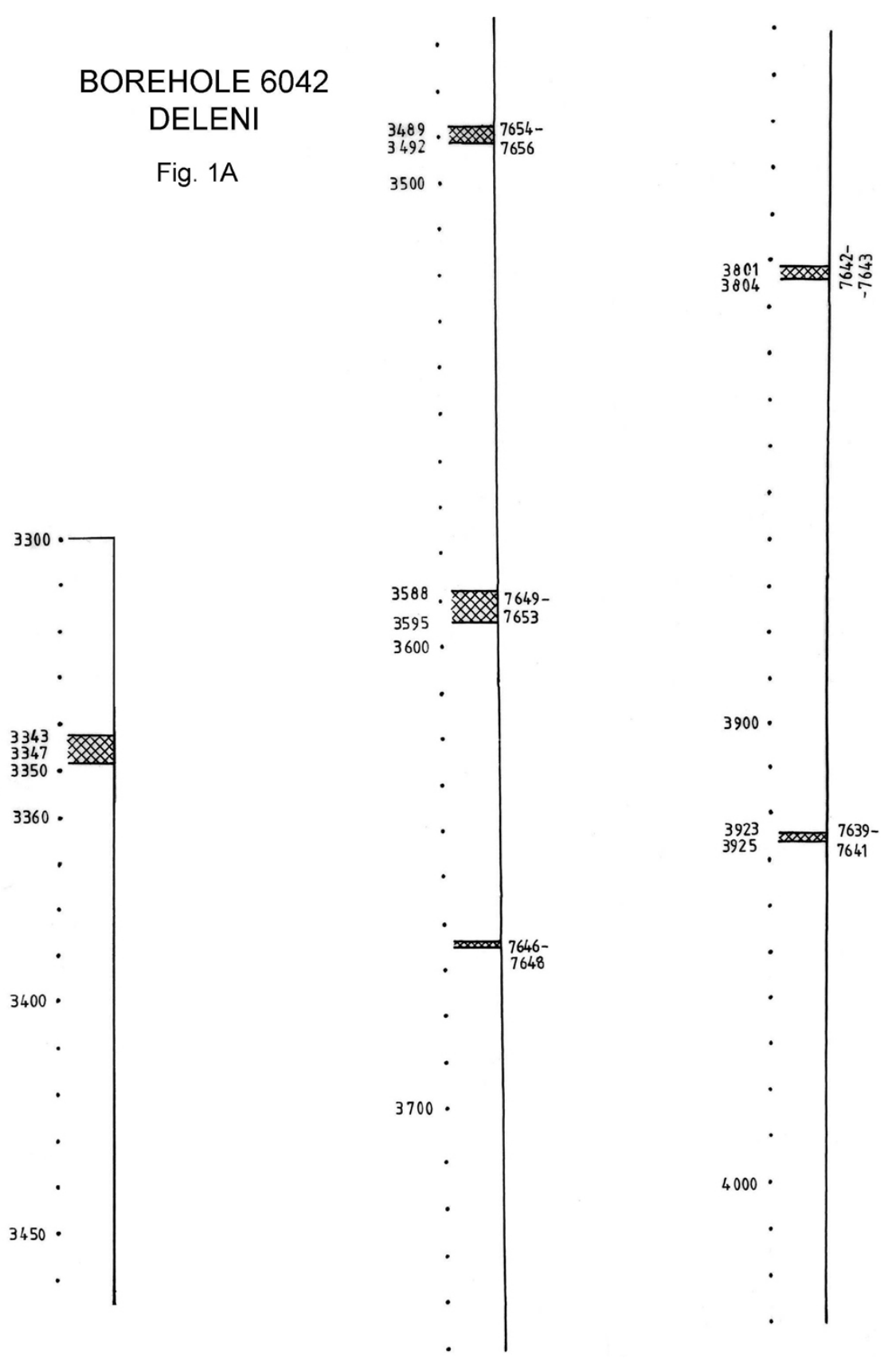

Fig. 1A - B - Sampled intervals with Mesozoic deposits from the borehole 6042 Deleni. 
THE MESOZOIC CARBONATE DEPOSITS FROM THE BOREHOLE 6042 DELENI

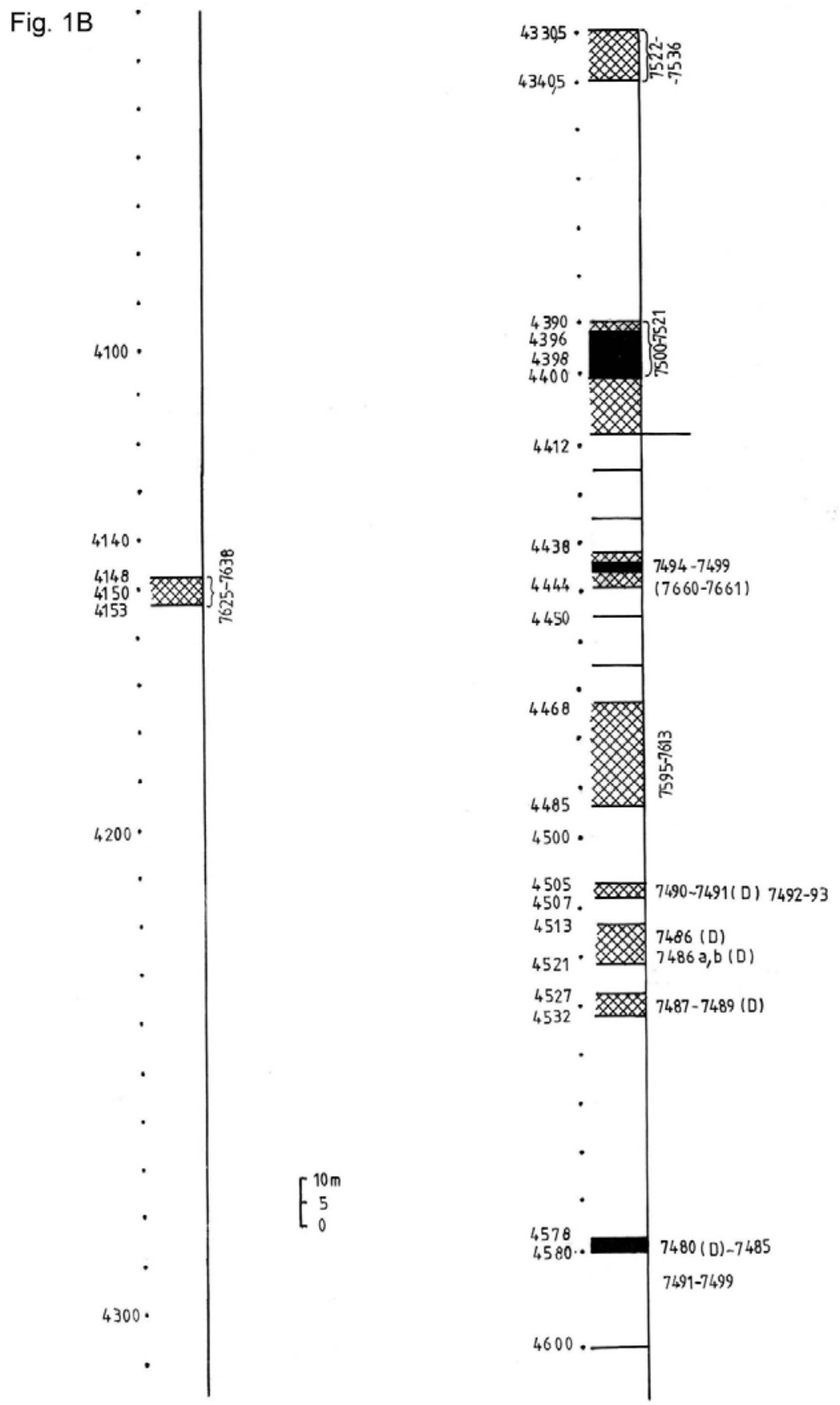




\section{LITOSTRATIGRAPHY}

\section{Dolomitic limestones with Cladocoropsis.}

The interpretation is based on 24 investigated samples (Fig.2D). The limestones consist of packstone, packstone-wackestone or dolomitised wackestone. The abiotic components are represented by micritic peloids of various sizes, as a result of either micritisation of bioclasts, or of the reworking of carbonate sediment. The dolomitisation process was undifferentiated - it affected both the matrix and the clasts, and lead to the formation of dolosparitic aggregates usually consisting of partially outlined rhombohedra that build-up in average $10-20 \%$ of the bulk rock. Locally, dolomitisation was more intense $(30-40 \%)$. The secondary nature of the dolomitisation process is also indicated by the screening effect of some bioclasts upon the $\mathrm{Mg}$ carbonate-rich solutions. The rock is locally characterised by the presence of diaclases filled with microdolosparitic material.

The bioclasts consist of frequent fragments of sclerospongia (Cladocoropsis mirabilis FELIX) (PI.I, figs. 1-4) that give the specific feature of these limestones. Besides fragments of bivalves, (rare) gastropods, foraminifers and calcareous algae are present. The microbial structures are represented by rivulariaceean type cyanobacteria (PI.I, figs. 7-8), bacinelloid-type nodules (PI.I, figs. 5-6), sometimes ending with a Lithocodium-type stage (PI.III, fig. 4), Lithocodium-type nodules (PI.III, fig.5), Hormathonema-type microbial deposits (PI.III, figs. 7-8) accompanied by small micritic aggregates and thin micritic crusts within the internal space of Cladocoropsis (PI.III, fig. 6), micritic microbial crusts around the Caldocoropsis and mollusc fragments.

Except for the cyanobacteria, the carbonate algae are relatively scarce. However, the most frequent species is Thaumatoporella parvovesiculifera (RAINERI) (PI.3, fig.3) while dasyclad fragments are very rare.

Foraminifers are abundant, represented both by agglutinated forms, as well as miliolids and involutinids. The following species were identified: Redmondoides lugeoni (SEPTFONTAINE) (PI.II, fig.6), Alveosepta jaccardi (SCHRODT) (PI.II, figs.12), Neokilianina rahonensis (FOURY \& VINCENT) (PI.II, figs. 3-4), Parurgonina caelinensis CUVILLIER, FOURY \& PIGNATI-MORANO (PI.II, fig.5; PI.III, fig.1), "Trocholina" sp., Andersenolina gr. alpina (LEUPOLD) (PI.II, figs. 7-8), ?Everticyclammina $\mathrm{sp}$. , Pseudocyclammina sp., ?Protopeneroplis sp., ?Arenobulimina sp., various agglutinated forms of textulariid-type, miliolids (PI.III, fig.2).

\section{Dolomites}

The study was performed on 96 samples (Fig.2B-D). The dolomites consist of medium- to coarse grained dolosparites (PI.IV, figs. 3-5). The dolomitisation affected a pre-existing carbonate sediment, as proven by the frequent bioclast and peloid "phantoms" identified in some rock varieties (PI.IV, figs.1-2). The process shows variable intensities, in some cases leading to a total overprint on the previous substrate. The shape of the dolomite rhombohedra ranges from anhedral to euhedral, and their sizes from 0.10 to $0.60 \mathrm{~mm}$. Occasionally crystals larger than $1 \mathrm{~mm}$ have been noticed. It is highly probable that the original carbonate clasts played the role of nucleation centres for the dolomite rhombohedra, as suggested by the darker nuclei including relic carbonate material.

Many crystals show growth zonation pattern during subsequent nucleation stages, with lighter external bands (PI.IV, figs. 4, 6). When the original sediment included 30 
porous spaces of a fenestral-type, the dolomite crystals developed around these voids, in a centripetal display (PI. IV, fig. 5). The pores left empty by the dolomitisation process were subsequently filled-in with a late, poikilitic-type sparite cement. Sometimes the fenestral space was occupied by geopetal sediments mainly consisting of fine- to medium-granular dolomitic detritus. Frequently the rocks are fissured; sometimes they reached the brecciation stage (PI.IV, figs. 7-8). As in the case of fenestral spaces, the fissures were filled with fine dolomite detritus. Opaque, dark-coloured iron oxi-hydroxides and/or organic matter represent other types of materials often identified in the studied dolomites (less than $1 \%$ of the volume in some rock varieties). Some of the rhombohedra are intensely fissured, most probably along the twinning planes; this process might have thus provided the fine filling material for the voids and fissures.

The bioclasts that could be identified in the dolomite matrix are first of all represented by foraminifers, such as "Trocholina "sp. (PI.IV, fig.1), Redmondoides Iugeoni (SEPTFONTAINE), Neokilianina rahonensis (FOURY \& VINCENT), miliolides, various agglutinated foraminifers. Fragments of Thaumatoporella parvovesiculifera (RAINERI) are also present. Among the dasyclads, only Salpingoporella annulata CAROZZI has been determined (PI.IV, fig.2).

\section{Limestones with cyanobacteria and Clypeina}

Twenty seven samples were collected from this unit (Fig.2A-B). In the 4151$3924 \mathrm{~m}$. interval the succession is represented mainly by wackestone-packstone and wackestone, with cyanobacteria and foraminifers. Rare echinoderm plates, bivalve and gastropod fragments, crustaceean coprolites, as well as fragments of dasyclads and Thaumatoporella are also noticeable. The cyanobacteria nodules range between 1 and 9-10 $\mathrm{mm}$; in general they are the major component of the rock. The nodules' structure is of a bacinelloid-type; however, some nodules consist of rivulariaceantype structures (PI.V, fig.8). Most of them suffered an intense micritisation process that finally led to the complete overprint of the original structure. The micrite peloids, usually $0.05-0.20 \mathrm{~mm}$ in size and showing rounded or oval shapes most probably originate from micritised bioclasts. Rare coarse grainstone intebeddings mainly consist also of cyanobacteria nodules, in principal of bacinelloid-type. Fragments of gastropods, foraminifers, fragments of dasyclad and Thaumatoporella are also present. The rock was subject to dolomitisation processes to a lesser extent. Rare rhombohedral crystals of reduced size $(0.10-0.13 \mathrm{~mm})$ subsequently most probably affected by dedolomitisation have been noticed. The wackestone-type facies including cyanobacteria nodules, foraminifers and Thaumatoporella dominates the top of this unit. Locally this facies is very scarce in foraminifers, and is characterised by the abundance of bacinelliform or micritic microbialitic nodules; the latter sometimes consist of small peloids of microbial-type. Such varieties indicate a very shallow facies, possibly even supratidal small ponds. Locally, the rock shows fenestrate features, the voids being filled with a fine granular dolomitic material.

In other cases the wackestone-type facies is dominated by Thaumatoporellatype structures (PI.V, fig.7). The sequence ends with peloidal grainstone / packstone with foraminifers and rare dasyclads, accompanied by fragments of bivalves, gastropods and crustacean coprolites. The micritic peloids consisting $50-60 \%$ of the rock show variable sizes, between 0.05 and $1.1 \mathrm{~mm}$, most of them resulting from bioclast micritisation. Foraminifers are the most abundant bioclasts. 
In the interval $3804-3801 \mathrm{~m}$. the succession consists of packstone and wackestone with ostracods, fragments of bivalves, foraminifers and fragments of dasyclads. The micritic peloids range between $0.10-0.20 \mathrm{~mm}$; miliolids are frequent in general.

Finally in the interval $3665-3664 \mathrm{~m}$. the deposits are represented by boundstone dominated by hermatypical recrystallized corals of thamnasterioidtype. Besides, sclerospongia of Chaetetopsis-type were noticed. The peloidal intrareef sediment contains fragments of bivalves and gastropods, foraminifers and "Tubiphytes". Within the same interval also coarse packstone-grainstone deposits with Bacinella and Lithocodium nodules, abundant echinoderm plates, fragments of bivalves and large recrystallized coral fragments (perireef sediment) were identified. In addition, annelid tubes and foraminifers (including Lenticulina) are present.

The following genera and species were identified in the succession: ?Everticyclammina sp., ?Gaudryina sp., Belorusiella sp., Patellovalvulina sp., Nautiloculina sp., Parurgonina caelinensis CUVILLIER, FOURY \& PIGNATI MORANO (PI.VI, figs.1-3), Redmondoides lugeoni (SEPTFONTAINE) (PI.VI, fig.4), Andersenolina sp. (PI.VI, fig.5), Lenticulina sp., Meandrospira sp. (PI.VII, fig.1), ?Protopeneroplis sp. (PI.VII, fig.2), Neotrocholina sp. (PI.VI, fig.6), Clypeina sulcata (ALTH) (PI. V, fig. 5), ?Salpingoporella sp. (PI.V, fig.6), ?Selliporella sp. (PI.V, figs. 1-4), Thaumatoporella parvovesiculifera (RAINERI) (PI.V, fig.7), Bacinella irregularis RADOIČIĆ, Lithocodium aggregatum ELLIOTT (PI.VII, fig.3), and Favreina salevensis (PAREJAS) (PI.VI, figs.7-8).

\section{Terrigenous and carbonate-terrigenous deposits}

On the top of the carbonate rocks, the borehole from Deleni crossed a terrigenous and carbonate-terrigenous succession.

Sandstones and sandy limestones are the corresponding rocks identified in the 3595-3587 $\mathrm{m}$ interval. The sandstones belong to the quartzo-lithical type ( $Q$ $=30-40 \%$; micas $-15-20 \%$ ) and they show a dominant siliceous cement (partly carbonate-rich, dolomitised). The bioclasts are represented by numerous sponge spicules, foraminifers and fragments of red algae. The foraminifers are mainly represented by species of the Hedbergella - Globigerinelloides and Gavelinella genera. The sandy limestones (3592-3591 m interval) consist of silty to fine arenitic quartz $(20-25 \%)$, bioclasts (fragments of bivalves, foraminifers, fragments of red algae) (20-25\%), and micas (3-5\%). Gavelinella and Hedbergella - Globigerinelloides are still dominant among foraminifers and rare nodosariides and Sabaudia minuta (HOFKER) (PI.VII, figs.4-5) are also present.

The 3492-3489 $\mathrm{m}$ interval is represented by siliceous shales with radiolarians. Quartz is present in relatively reduced amounts $(10-15 \%$, up to $30-40 \%$ in interbeddings showing a more pronounced terrigenous character). Micas range between $5-15 \%$. Films of opaque minerals (iron oxides-hydroxides) were frequently noticed. The cement is siliceous, microcrystalline. The biophase mainly consists of radiolarians, rare sponge spicules and rare foraminifers (including heterohelicides).

Samples of silty-clayey to fine arenitic limestones have been recovered from the 3347-3342 m interval, with quartz grains ranging between $5-20 \%$, and bioclasts between $15-20 \%$. The cement has a carbonate nature, being intimately mixed with microcrystalline silica. Bioclasts are mainly represented by foraminifers, besides which radiolarians, sponge spicules and calcispherulides have been noticed. The dominant foraminifera are Hedbergella - Globigerinelloides, Globotruncana (PI.VII, fig.6-8) and Heterohelix, while most of the calcispherulides belong to Pithonella. 


\section{BOREHOLE 6042 DELENI}

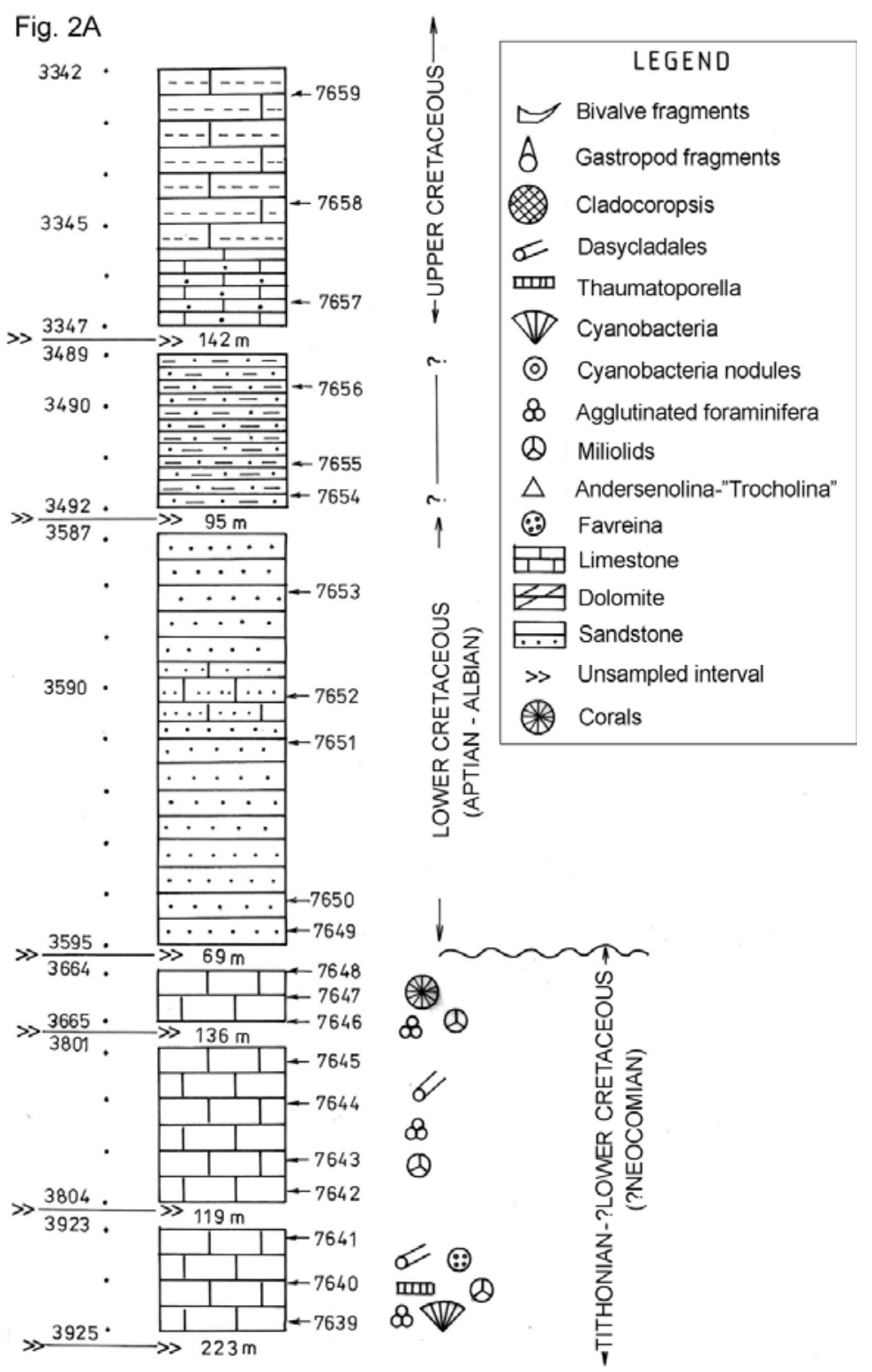

Fig. 2A - D - Lithologic succession of the Mesozoic deposits from the borehole 6042 Deleni. 
IOAN I. BUCUR, MARCEL-ADRIAN PITEIU, EMANOIL SĂSĂRAN

Fig. 2B

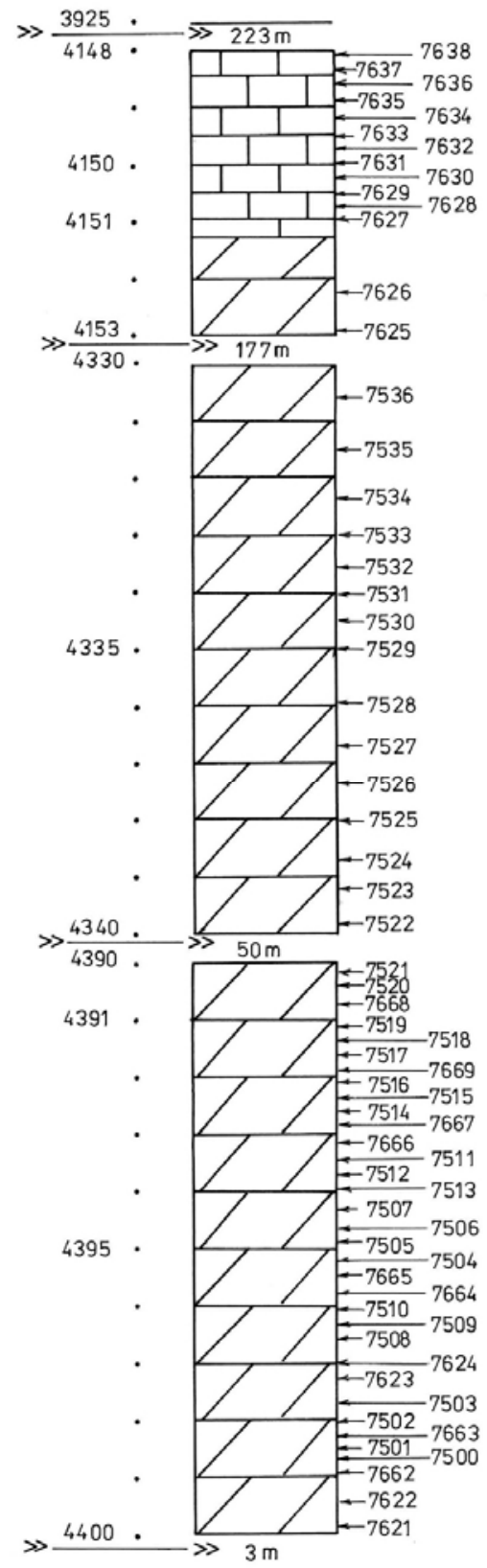

$\stackrel{8}{\Delta} \nabla$

(3)

$\forall$ (ㅇ)

(5)

$\$ 8$

$B$

8

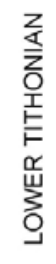

8

8
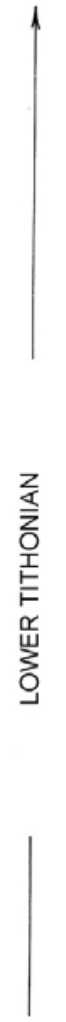

8

$z$
$\frac{\alpha}{0}$
$\frac{0}{x}$
$\frac{1}{4}$
$\sum_{x}^{\Sigma}$

8

8

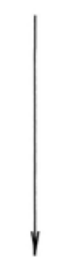


THE MESOZOIC CARBONATE DEPOSITS FROM THE BOREHOLE 6042 DELENI

Fig. 2C

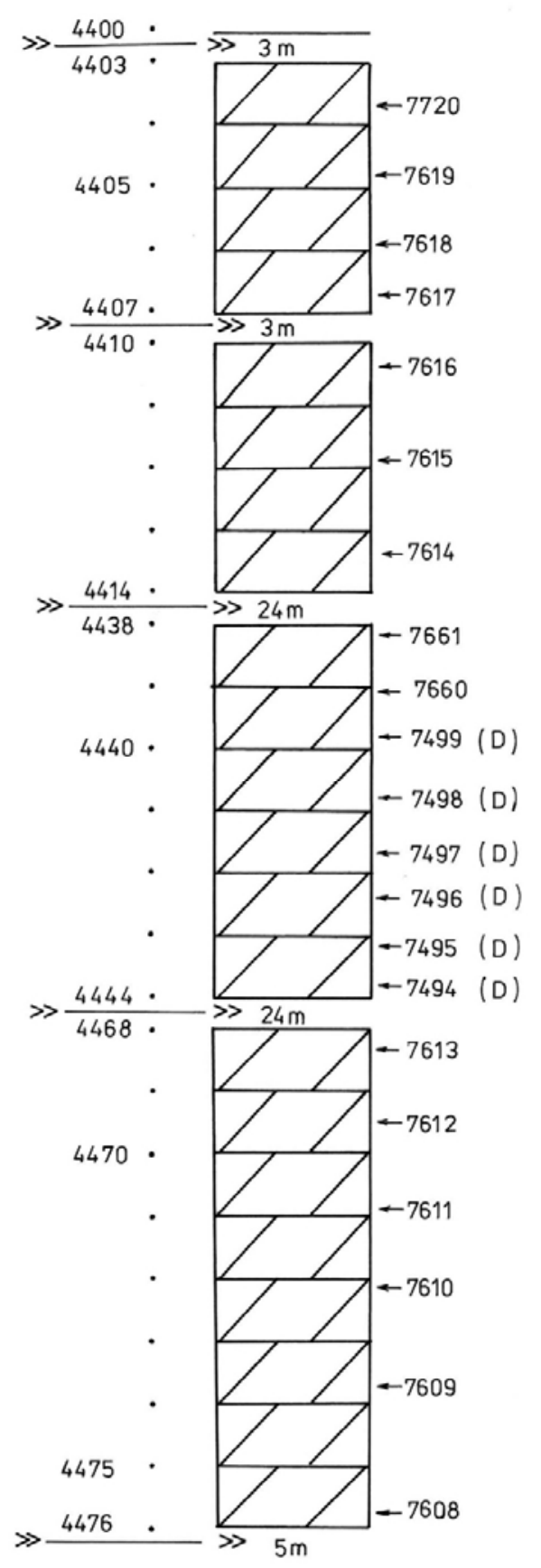


IOAN I. BUCUR, MARCEL-ADRIAN PITEIU, EMANOIL SĂSĂRAN

Fig. 2D

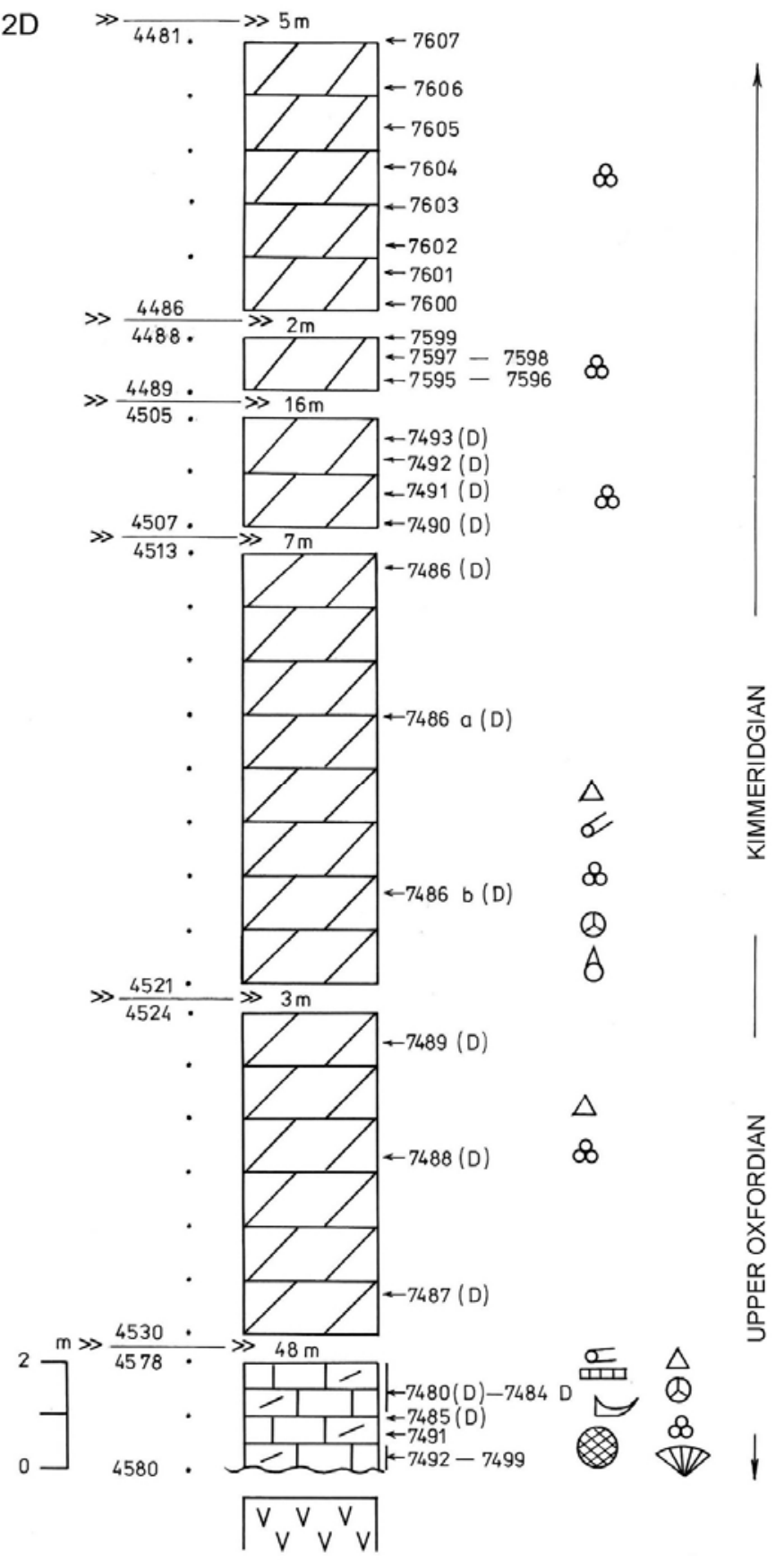




\section{BIOSTRATIGRAPHIC REMARKS}

The foraminiferal assemblage identified in the Limestones with Cladocoropsis includes 4 species that are characteristic for the Tethyan Late Jurassic: Redmondoides lugeoni (SEPTFONTAINE), Alveosepta jaccardi (SCHRODT), Neokilianina rahonensis (FOURY \& VINCENT) and Parurgonina caelinensis CUVILLIER, FOURY \& PIGNATIMORANO. Among them, Alveosepta jaccardi is stratigraphically restricted to the Late Oxfordian-Early Kimmeridgian (Maync, 1960; Hottinger, 1967; Septfontaine et al., 1991). The lower limestone unit can be thus attributed to this time-interval (Fig.3).

Regarding the dolomites, among the "phantom"-foraminifers that could have been identified, two species belong to the same Late Jurassic group: Redmondoides lugeoni (SEPTFONTAINE) and Neokilianina rahonensis (FOURY \& VINCENT) (Bassoullet, 1997). Based on these species, the dolomite unit can be assigned to the Kimmeridgian-Late Tithonian interval, characterized by the presence of the species $N$. rahonensis.

The limestones with cyanobacteria include, starting with sample $7638(\mathrm{~m}$. 4150-4148), the species Parurgonina caelinensis having the upper limit restricted to the Middle Tithonian (Bassoullet, 1997). At about $125 \mathrm{~m}$ above, the limestones in this unit include Clypeina sulcata (ALTH) accompanied by Redmondoides lugeoni (SEPTFONTAINE), and Favreina salevensis PAREJAS. This association indicate the Late Tithonian. Starting with $\mathrm{m}$. 3804 till $\mathrm{m}$. 3664, where the carbonate succession ends, the foraminiferal and algal association does not provide any clue for age assignments. However, some of the foraminifers attributed to genera Protopeneroplis and Meandrospira resemble Protopeneroplis ultragranulata (GORBACHIK), and Meandrospira favrei (CHAROLLAIS, BRÖNNIMANN \& ZANINETTI). Based on these arguments, we assigned the last $100-140 \mathrm{~m}$ of limestones to the Early Cretaceous (Berriasian-?Valanginian) (Altiner, 1991; Bucur et al., 1995); this assignment is however questionable.

The terrigenous rocks on the top of the succession belong to the Cretaceous. The sandstones and sandy limestones in the 3595-3587 m interval contain foraminifers of the Hedbergella, Globigerinelloides and Gavelinella genera, besides which Sabaudia minuta (HOFKER) has been identified. Keeping into account that the latter species does not have a post-Albian extension (Chiocchini et al., 1983; Arnaud-Vanneau \& Chiocchini, 1985), the whole unit may be assigned to the Aptian-Albian. There are no clear arguments for dating the shales with radiolarians in the 3492-3489 $\mathrm{m}$ interval. However, based on the fact that they contain species of the genus Heterohelix with the first species occuring at the end of the Albian, we can assign a Late Cretaceous (probably the lower part of Late Cretaceous) age to these rocks. Finally, the globotruncanids identified in the latter investigated interval (m. 3347-3342) indicate a Late Cretaceous (Senonian) age.

\section{PALEOENVIRONMENTAL INTERPRETATION}

The carbonates studied were deposited in a shallow environment (carbonate platform), that evolved from an external platform facies with Cladocoropsis and foraminifers (the limestones with Cladocoropsis) to an internal one (shallow subtidal, intertidal to supratidal) dominated by cyanobacteria (the Limestones with cyanobacteria), followed by a platform margin (reef and para-reef environments) (the 


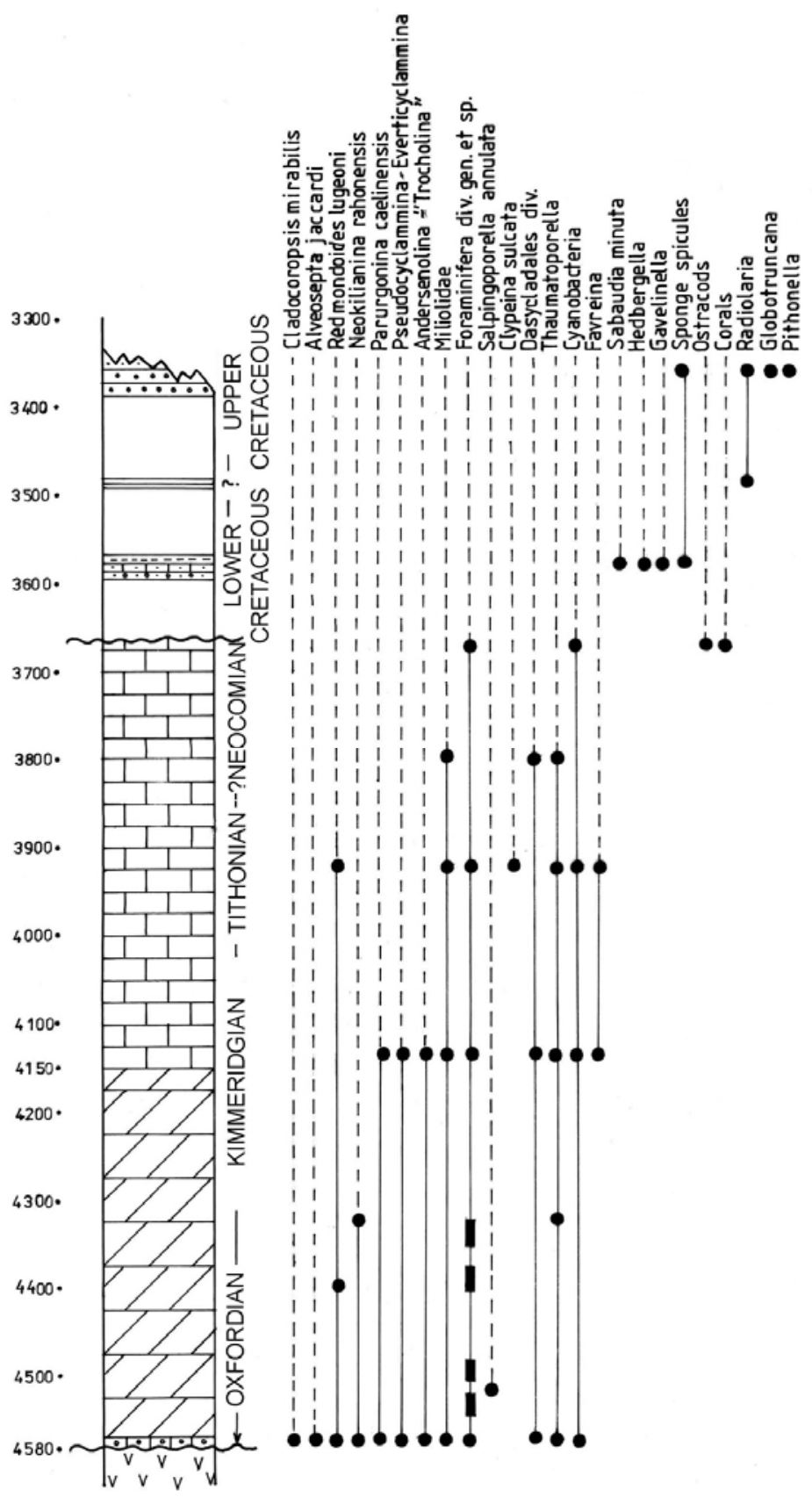

Fig. 3 - Biostratigraphic repartition of the main microfossils identified in the Mesozoic deposits from the borehole 6042 Deleni. 
coral limestones at the top of the succession). It is difficult to define the environment of deposition for the limestones that evolved in the dolomitic unit. However, dolomitisation was for sure a secondary process that probably affected the limestones during successive stages of their formation, from the penecontemporaneus (quasi-sindepositional) stage to late diagenesis. The source of magnesium for the CaMg $\left(\mathrm{CO}_{3}\right)$ is not obvious. Its transport was anyway provided by solutions circulating through the areas of minimum resistance in the sediment (pores, fissures, diaclases).

The terrigenous deposits mark the transition to deep waters facies with pelagic foraminifers accompanied in the lower part by benthic elements (AptianAlbian with Sabaudia), the pelagic feature becoming dominant towards the top (radiolarians, pithonellas, globotruncanids).

\section{CONCLUSIONS}

The borehole 6042 Deleni crossed Mesozoic deposits along 916 m thickness. Three carbonate units were separated: 1) limestones with Cladocoropsis; 2) dolomites and 3) limestones with cyanobacteria and Clypeina. Based on the microfossils identified in thin sections, the three carbonate units were attributed to the Late Oxfordian-Tithonian (?Neocomian). The terrigenous and carbonate-terrigenous deposits at the top of the limestones were assigned partly to the end of the Early Cretaceous (Aptian-Albian), and partly to the Late Cretaceous.

The Jurassic limestones and dolomites formed within a carbonate platform that evolved from an external to an internal environment. Both the facies and the micropaleontological content of these deposits are similar to the Oxfordian-Tithonian carbonate deposits in the Transylvanian units of the Southern Apuseni Mountains. The terrigenous and carbonate-terrigenous deposits at the top of the succession indicate a deep water environment.

\section{Acknowledgements}

Thanks are due to our colleagues Janeta Pop and Monica Mereu for the redrawing of the figs. 1-3 and to Dr. Dana Pop for the English translation of the manuscript.

\section{REFERENCES}

Altiner D., 1991, Microfossil biostratigraphy (mainly foraminifers) on the Jurassic-Lower Cretaceous carbonate successions in north-western Anatolia (Turkey). Geologica Romana, 27, p.167-213, Roma

Arnaud-Vanneau A. \& Chiocchini M., 1985, Le genre Sabaudia Charollais et Brönnimann 1965 (Foraminifère benthique crétacé) et ses différentes espèces. Revue de Micropaléntologie, 28/1, p3-22, Paris.

Chiocchini M., Mancinelli A. \& Romano A., 1984, Stratigraphic distribution of benthic foraminifera in the Aptian, Albian and Cenomania carbonate sequences of the Aurunci and Ausoni Mountains (Southern Lazio, Italy). Benthos '83; $2^{\text {nd }}$ Int. Symp. Benthic Foraminifera (Pau, April 1983), p.167-181, Pau.

Bassoullet, J.-P., 1997, Foraminifères - Les Grands Foraminifères. In: Groupe Français d'Étude du Jurassique (1997). - Biostratigraphie du Jurassique ouest-européen et méditerranéen: zonations parallèles et distribution des invertébrés et microfossiles. Cariou, E. \& Hantzpergue, 
P. (coord.). - Bull. Centre Rech. Elf Explor. Prod., Mém.17, p. 293-304, Pau.

Bucur I.I., Conrad M.A., Radoičić R., 1995, Foraminifers and calcareous algae from the Valanginian limestones in the Jerma River Canyon, Eastern Serbia. Revue de Paléobiologie, 14/2, p.349-377, Genève.

Hottinger L., 1967, Foraminifères imperforés du Mésozoique marocain. Notes et Mémoires Serv. Géol., 209, 168 p., Rabat

Maync W., 1960, Biocaractères et analyse morphologique des espèces jurassiques du genre Pseudocyclammina (Foraminifères) II. Pseudocyclammina jaccardi (Schrodt). Revue de Micopaléontologie, 3/2, p.104-118, Paris

Săndulescu M., 1984, Geotectonica României. 336 p., ed. Tehnică, Bucureşti.

Săndulescu M. \& Visarion M., 1978, Considérations sur la structure tectonique du subasment de la Depression de Transylvanie. Dări de Seamă, Institutul de Geologie şi Geofizică, LXIV/5, p. 153-173, Bucureşti

Septfontaine M., Arnaud-Vanneau A., Bassoullet J.-P., Gusic Y., Ramalho M. \& Velic I., 1991, Les foraminifères imperforés des plates-formes carbonatées jurassiques: état des connaissances et perspectives d'avenir. Bull. Soc. Vaud. Sc. Nat. 80/3 (Bull. 312 Géol. Musée Lausanne), p.255-277, Lausanne

\section{PLATES}

Plate I

Fig. 1-4 - Cladocoropsis mirabilis FELIX. 1-3: oblique sections; 1-sample 26/03, x 6.2; 2 sample 7491, x 6.2; 3-sample 7491, x 12.5; 4: longitudinal section, sample 7494, $\times 6.2$.

Fig. 5-6 - Bacinella-like nodules. 5: sample 26a/03, x 12.5; 6: sample 7491, x 12.5 .

Fig. 7-8 - Rivulariacean-like cyanobacteria. 7: sample 26/03, x 25; 8: sample 7496, x 12.5 .

Plate II

Fig. 1-2 - Alveosepta jaccardi (SCHRODT). 1: equatorial section, sample 25/03, x 50; 2: axial section, sample $26 / 03, x 50$.

Fig. 3-4 - Neokilianina rahonensis (FOURY \& VINCENT). Longitudinal sections. 3: sample $26 / 03$, x 25; 4: sample 7491a, x 25 .

Fig. 5 - Parurgonina caelinensis CUVILLIER, FOURY \& PIGNATTI MORANO. Oblique section, sample 7496, x 25.

Fig. 6 - Neokilianina rahonensis (FOURY \& VINCENT) and Redmondoides lugeoni (SEPTFONTAINE). Oblique and longitudinal-oblique sections, sample 7480(D), $\times 25$.

Fig. 7-8 - Andersenolina gr. alpina (LEUPOLD). Subaxial sections. 7: sample 26/03, x 50; 8: sample 7491, x 50.

Plate III

Fig. 1 - Parurgonina caelinensis CUVILLIER, FOURY \& PIGNATTI MORANO. Detail of the wall structure, sample 7491a, x 50 .

Fig. 2 - Miliolid foraminifer. Sample 7493, x 50.

Fig. 3 - Thaumatoporella parvovesiculifera (RAINERI). Sample 7491a, x 25.

Fig. 4 - Bacinella irregularis RADOIČIĆ-Lithocodium aggregatum ELLIOTT. Sample 
$7497, \mathrm{x} 12.5$

Fig. 5 - Lithocodium nodule. Sample 7480(D), x 25.

Fig. 6 - Microbial sediment inside on open space of Cladocoropsis mirabilis skeleton. Sample 7495, x 50 .

Fig. 7-8 - Microbial structures of Hormathonema type inside the internal spaces of Cladocoropsis (8 = enlargement of fig.7). Sample 7483(D); 7 × 50; 8 × 100.

Plate IV

Fig. 1-2 - Dolomite with phantome-like clasts, including some well preserved biosclasts: "Trocholina" sp. (fig.1) and Salpingoporella annulata CAROZZI (fig.2). 1: sample 7488(D), x 50; 2: sample 7486a(D), x 50 .

Fig. 3 - Medium-grained dolomite. Sample 7628, x 12.5 .

Fig. 4, 6 - Coarse-grained dolomite with zoned rhombohedra. 4: sample 7610/2, x 25; 6: sample $7661, \mathrm{x} 12.5$.

Fig. 5 - Open space in a coarse-grained dolomite filled with poikilitic sparry calcite. Sample 7612, x 12.5.

Fig. 7-8 - Brecciated dolomite. 7: sample 7498(D), x 6.2; 8: sample 7616, x 6.2.

\section{Plate V}

Fig. 1-4 - ?Seliporella sp. Tangential sections through laterals. 1: sample 7535, x 25; 2, 3 : sample 7630, x 25; 4: sample 7631, x 25.

Fig. 5 - Clypeina sulcata (ALTH). Tangential section through a verticil, sample 7641/2, $\times 50$.

Fig. 6 - ?Salpingoporella sp. Transverse section, sample 7644, x 50.

Fig. 7 - Thaumatoporella parvovesiculifera (RAINERI) with small protuberances (?reproductive structures). Sample 7640, x 50.

Fig. 8 - Rivulariacean-like cyanobacteria. Sample 7634, x 25.

\section{Plate VI}

Fig. 1-3 - Parurgonina caelinensis CUVILLIER, FOURY \& PIGNATTI MORANO. Subaxial sections, sample 7638, x 25 .

Fig. 4 - Redmondoides lugeoni (SEPTFONTAINE). Subaxial section, sample 7639, x 25.

Fig. 5 - Andersenolina sp. Subaxial section, sample 7636, x 50 .

Fig. 6 - Neotrocholina sp. Subaxial section, sample 7648, $\times 50$.

Fig. 7-8 - Favreina salevensis (PAREJAS). 7: sample 7631, x 25; 8: sample 7635, x 25.

\section{Plate VII}

Fig. 1 - Meandrospira sp. Transverse section. Sample 7646, x 50.

Fig. 2 - ?Protopeneroplis sp. Oblique section, sample 7647, x 50.

Fig. 3 - Lithocodium aggregatum ELIOTT. Sample 7647, x 25.

Fig. 4-5 - Sabaudia minuta (HOFKER). 4: transverse section; 5: longitudinal section through the embrionar apparatus, sample 7652/2, x 50.

Fig. 6-8 - Globotruncana div. sp. 6: sample 7657, x 50; 7: sample 7658, x 50; 8: sample $7659, \times 50$. 

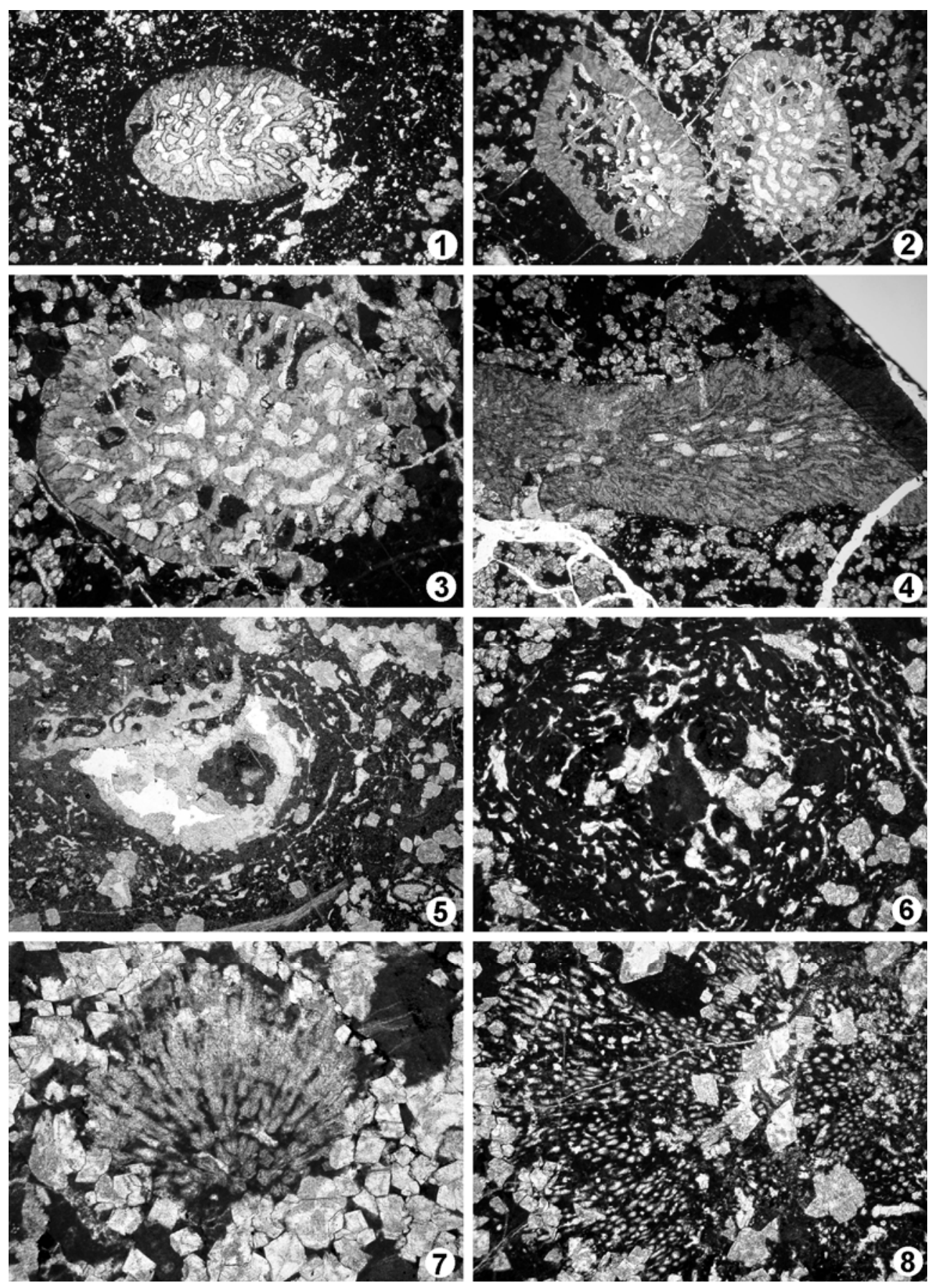
Plate II
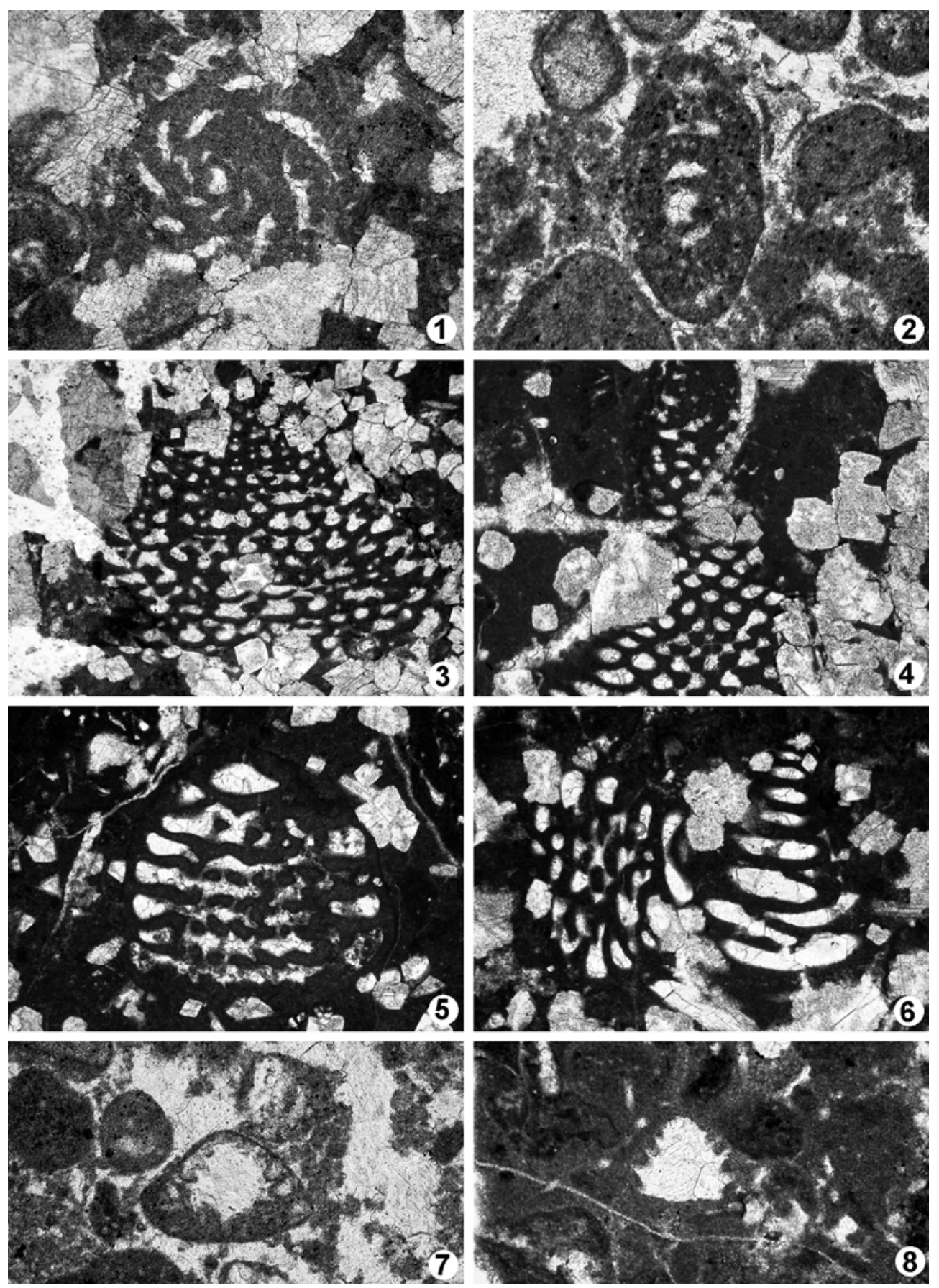
Plate III
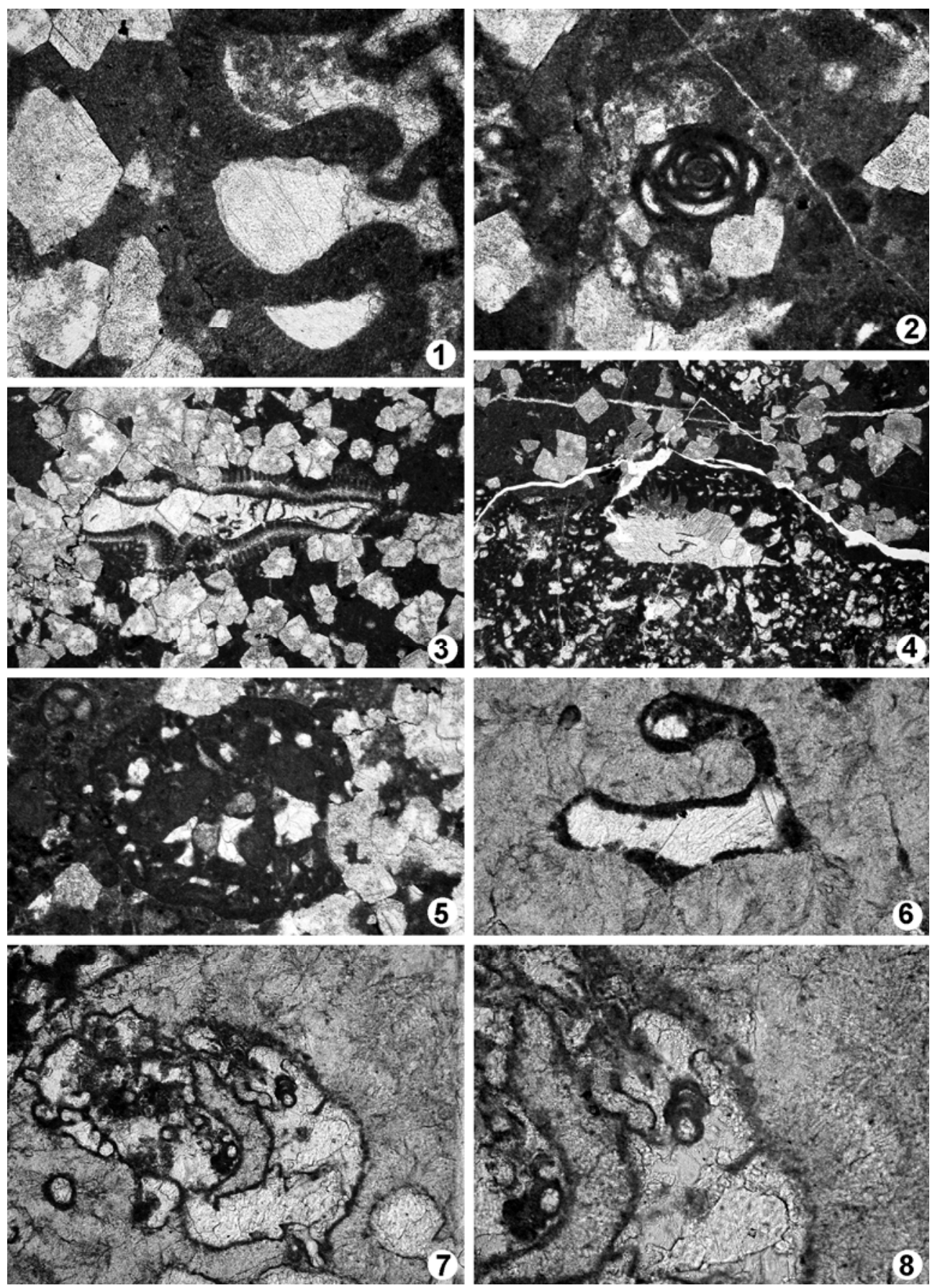
Plate IV
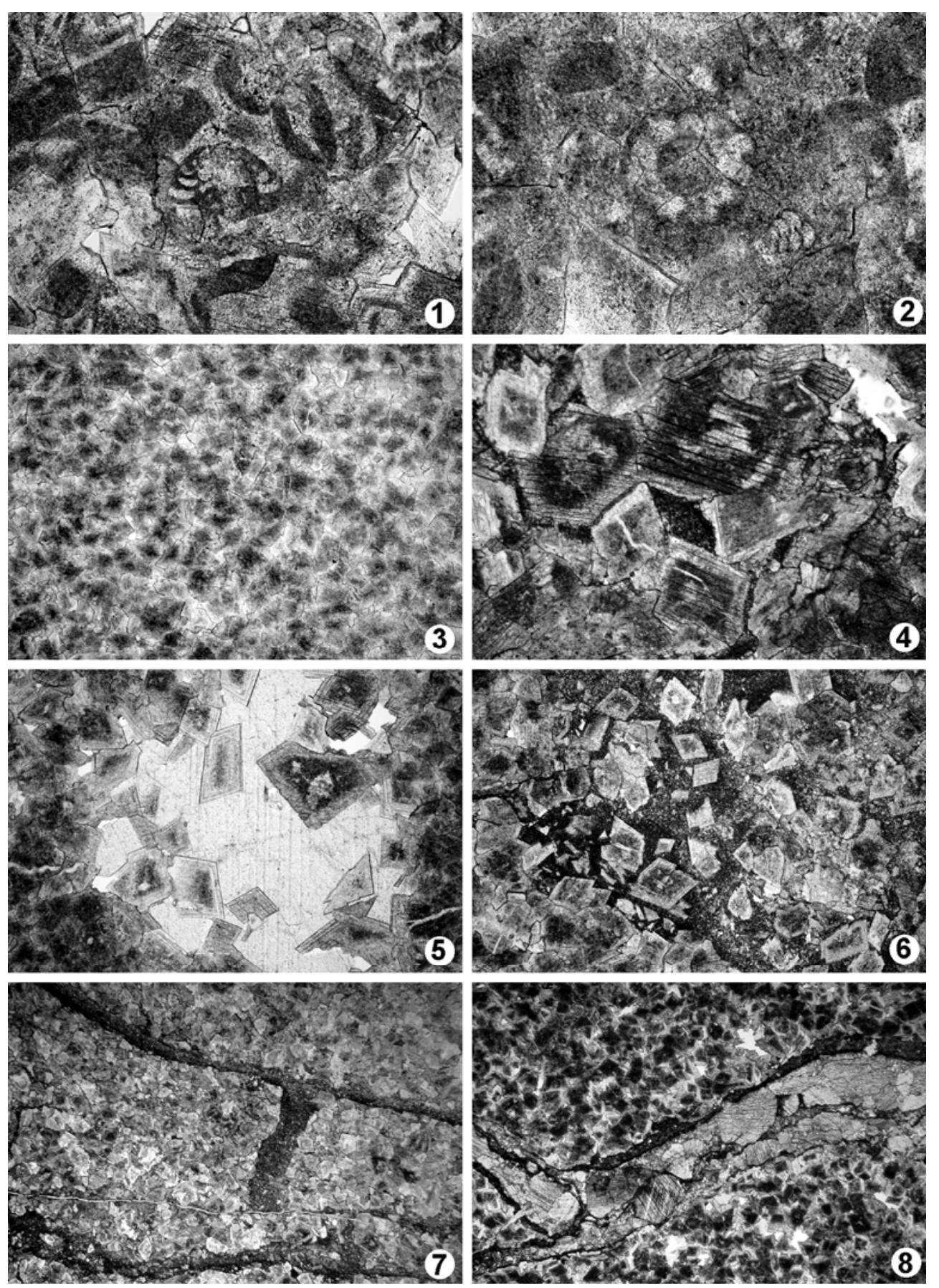
Plate V
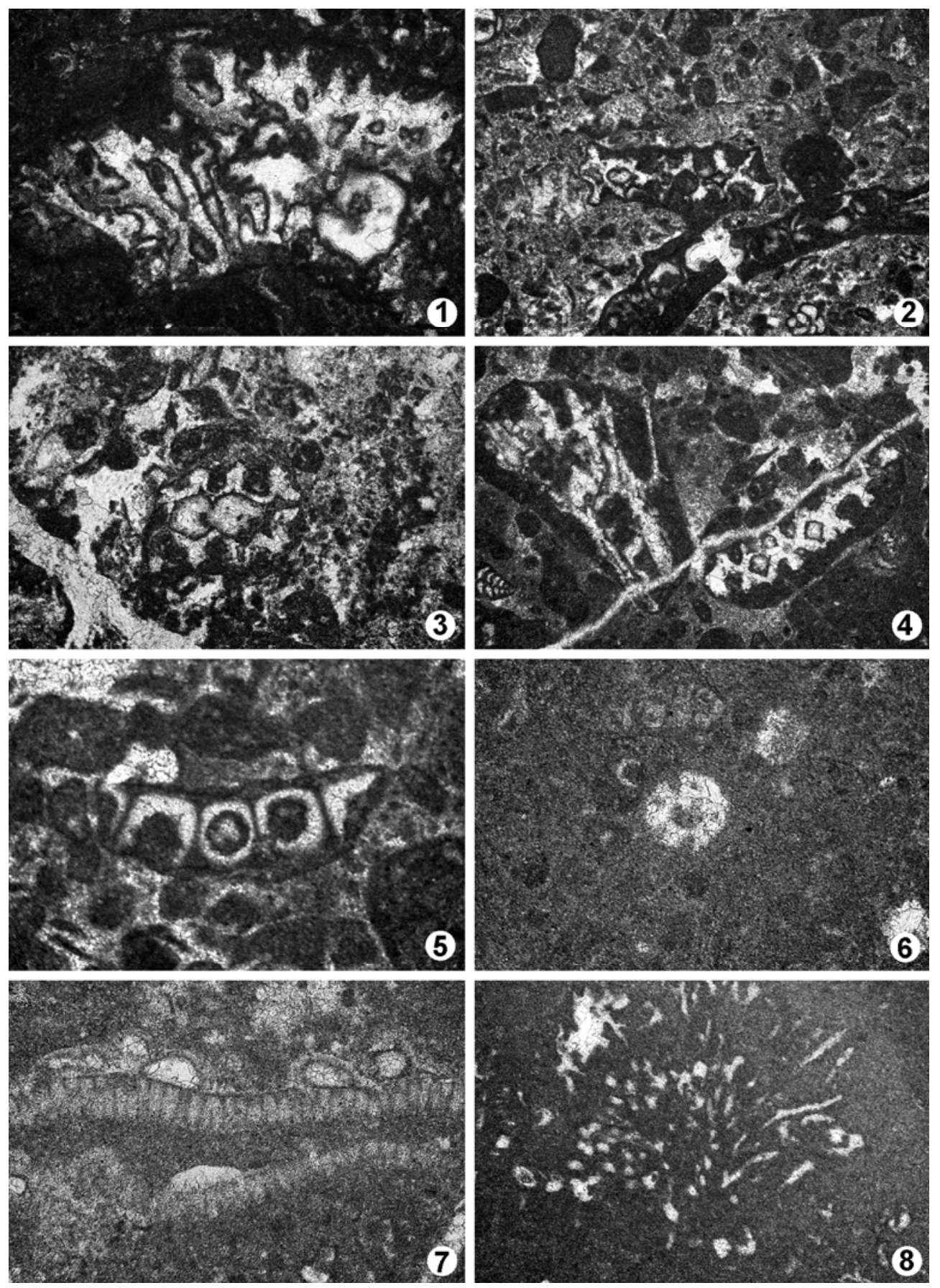
Plate VI
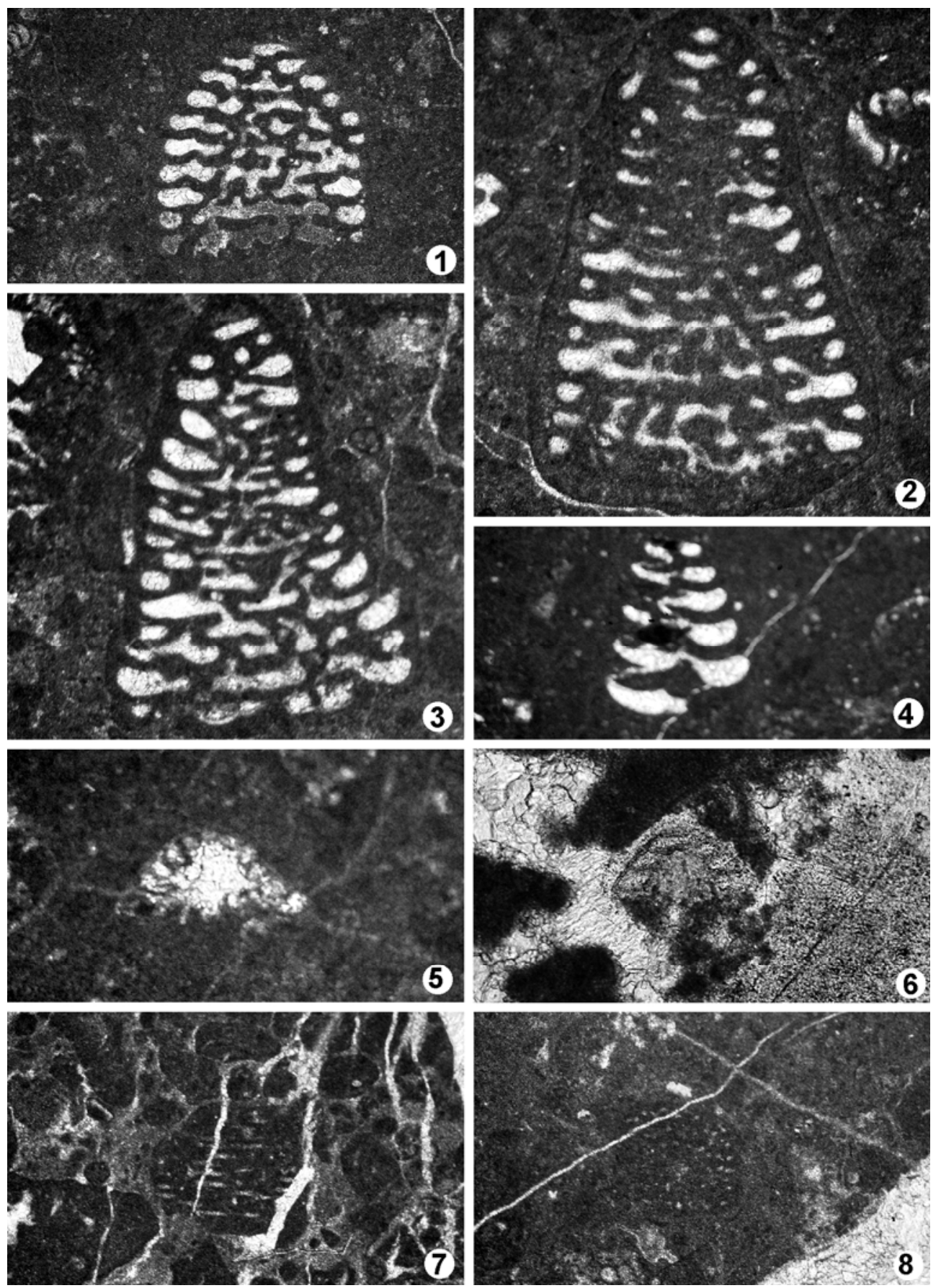
Plate VII
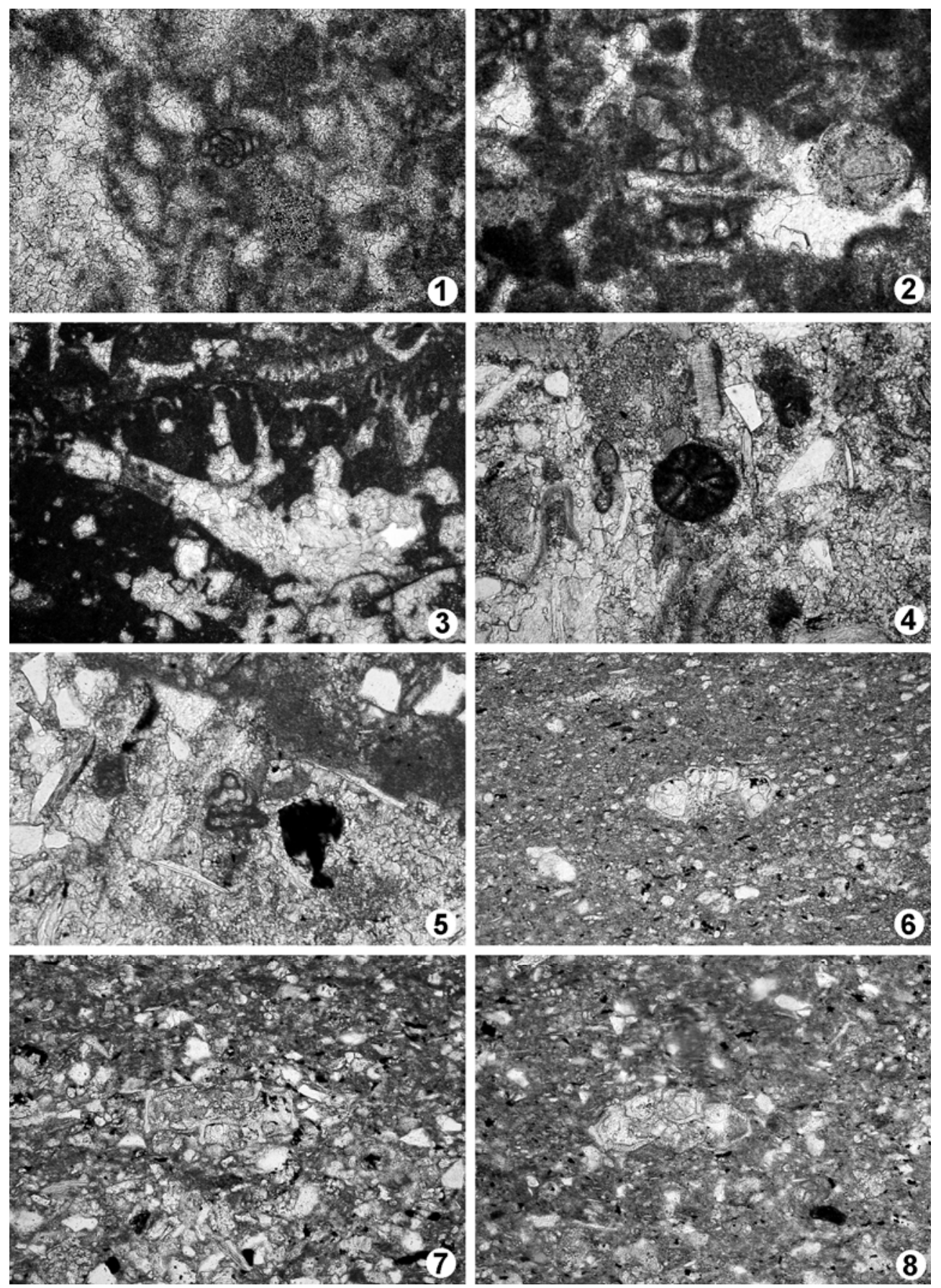